\title{
H1-3 Gene
}

National Cancer Institute

\section{Source}

National Cancer Institute. H1-3 Gene. NCI Thesaurus. Code C162861.

This gene is involved in nucleosome condensation into higher-order structures. 